\title{
Tissue inhibitor of metalloproteinases and collagenase inhibitory activity in lung secretions from patients with chronic obstructive bronchitis: effect of corticosteroid treatment
}

\author{
D BURNETT, J J REYNOLDS, R V WARD, S C AFFORD, R A STOCKLEY \\ From the Lung Immunobiochemical Research Laboratory, Clinical Teaching Block, General Hospital, \\ Birmingham, and the Cell Physiology Department, Strangeways Research Laboratory, Cambridge
}

ABSTRACT Tissue inhibitor of metalloproteinases (TIMP) and collagenase inhibitory activity were measured in the sputum from nine subjects with chronic bronchitis before and five days after treatment with corticosteroid (oral prednisolone, $40 \mathrm{mg}$ daily). The mean sputum TIMP concentrations for eight of the nine subjects increased from 3.1 (SD 0.87$) \mu \mathrm{g} / \mathrm{ml}$ to $5.8(1.9) \mu \mathrm{g} / \mathrm{ml}(2 \mathrm{p}<$ 0.005). Similarly, the mean collagenase inhibitory activity in the sputum of eight of the nine subjects increased from $1.53(1 \cdot 1) \mathrm{U} / \mathrm{ml}$ to $2.69(0.92) \mathrm{U} / \mathrm{ml}(2 \mathrm{p}<0.05)$. The TIMP concentrations in sputum exceeded the collagenase inhibitory activity, suggesting that a proportion of the TIMP was inactive. TIMP inactivity was not due to prior complexing with enzyme since the molecular weight of sputum TIMP (27 500) was similar to that described for the purified protein (28000-28 500). Preliminary studies showed the presence of TIMP in bronchoalveolar lavage samples (range of six specimens $0.45 \mathrm{ng} / \mathrm{ml}-2 \cdot 1 \mu \mathrm{g} / \mathrm{ml}$, median $53 \mathrm{ng} / \mathrm{ml}$ ). Collagenase inhibitory activity was detected in only two of these six lavage samples, suggesting that the TIMP was totally inactive in the other four samples. The significance of the metalloproteinase-inhibitor balance in the pathogenesis of chronic lung disease requires further study.

The pathogenesis of acute and chronic lung diseases is poorly understood but evidence suggests that proteolytic enzymes derived from leucocytes or pathogens play a part in causing lung destruction. ${ }^{12}$ The "proteinase-antiproteinase" theory of lung disease proposes that the proteinase inhibitors of the normal lung prevent tissue digestion by extracellular proteinases. Should the proteinases overwhelm the inhibitors, however, tissue destruction occurs. Specifically, neutrophil serine elastase activity is thought to be important in the pathogenesis of emphysema since $(a)$ elastases cause, in experimental animals, pathological changes characteristic of emphysema ${ }^{3}$ and $(b)$ inherited deficiency of $\alpha_{1}$ antitrypsin, the major serum inhibitor of serine proteinases, is associated with the early development of

\footnotetext{
Address for reprint requests: Dr David Burnett, Lung Immunobiochemical Research Laboratory, Clinical Teaching Block, General Hospital, Birmingham B4 6NH.
}

Accepted 1 July 1986 spontaneous emphysema. ${ }^{4}$ Consequently, most studies of the biochemical basis of several lung diseases have been concerned with elastases and antielastases.

Several metalloproteinases, including metalloelastase, ${ }^{56}$ collagenase, $^{7}$ and enkephalinase, ${ }^{8}$ have been described in lung secretions and tissue. These $\frac{7}{O}$ enzymes are thought to be pathologically important since it has been suggested that the lung is relatively $N$ deficient in metalloproteinase inhibitors. ${ }^{9}$ Little is known, however, of the inhibitors of metalloproteinases within the lung.

Tissue inhibitor of metalloproteinases (TIMP) is a protein of molecular weight 28000 , which has been $\stackrel{0}{C}$ described in several body fluids and connective tissue $\mathbb{\Phi}$ culture media. ${ }^{10}$ TIMP is synthesised by several cell types, including epithelial cells, ${ }^{10}$ fibroblasts, ${ }^{11}$ and alveolar macrophages, ${ }^{12}$ and is thought to be the major connective tissue inhibitor of metalloproteinases. The distribution of TIMP in the human $\AA$ lung has not been studied and it is not known whether it is present or active in lung secretions. 
The purpose of the present study was to investigate the presence and activity of TIMP in sputum from patients with chronic obstructive bronchitis. Bronchoalveolar lavage samples were also investigated to determine whether active TIMP is present in the lower respiratory tract. Corticosteroids have been reported to increase the synthesis of TIMP by connective tissue cells in culture ${ }^{13}$ and may therefore influence the in vivo production of TIMP by lung tissues. In this paper we report the effect of corticosteroid treatment on sputum levels of TIMP and collagenase inhibitory activity.

\section{Methods}

\section{RADIOIMMUNOASSAY OF TIMP}

TIMP concentrations in sputum samples were measured by a solid phase radioimmunoassay. Sigma cell microcrystalline beads ( $20 \mu \mathrm{m}$; Sigma S3504 type 20$)$ were activated with cyanogen bromide and bound to sheep antibodies to human TIMP, in a manner similar to that described for binding to Sepharose. ${ }^{10} \mathrm{~A}$ maximum sample volume of $50 \mu \mathrm{l}$ was incubated with the antibody coated beads in $1.0 \mathrm{ml}$ of $\mathrm{Tris} / \mathrm{HCl}$ (buffer), $\mathrm{pH} 7 \cdot 3$, containing $0 \cdot 15 \mathrm{M} \mathrm{NaCl}, 0 \cdot 05 \%$ (v/v) NP40 (Calbiochem), $1 \mathrm{mg} / \mathrm{ml}$ ovalbumin (Calbiochem), $5 \mathrm{mmol} / \mathrm{l} \mathrm{NaI}, 0.02 \% \mathrm{Na}$ azide, and $50 \mu \mathrm{l}$ of TIMP labelled with iodine 125 (about 40000 counts/min). The mixture was rotated for 18-24 hours and centrifuged, and the supernatant removed and washed twice with $0.15 \mathrm{~mol} / 1 \mathrm{NaCl}$ containing $0.1 \%$ NP40. After further centrifugation the ${ }^{125} \mathrm{I}$ TIMP in the pellet was measured with a Packard Multi-Prias 4 gamma counter. The method was calibrated by known dilutions of pure TIMP. ${ }^{14}$ Duplicate assays gave results within 5\%; the lower limit of detection was $10 \mathrm{ng} \mathrm{TIMP} / \mathrm{ml}$.

\section{COLLAGENASE INHIBITORY ACTIVITY}

The collagenase inhibitory activity of samples was assayed by their ability to inhibit the digestion of rat skin collagen, labelled with carbon 14 , by rabbit skin collagenase, as described previously. ${ }^{14}$ Results were expressed as units $/ \mathrm{ml}$ with reference to the activity of pure TIMP ( 4200 units $/ \mathrm{mg}$ ). The lower limit of detection was $0.05 \mathrm{U} / \mathrm{ml}$.

\section{DAILY VARIATION OF SPUTUM TIMP AND \\ COLLAGENASE INHIBITION}

Sputum samples were collected from six patients with chronic obstructive bronchitis ${ }^{15}$ on five consecutive days over a four hour period (early morning, after they had got up). The patients were clinically stable with no overt evidence of an infective exacerbation. The mean age of the subjects was 58 (SD 4.9) years; four were men. The mean ratio of forced expired volume in one second to forced vital capacity $\left(\mathrm{FEV}_{1} / \mathrm{FVC}\right.$ ) was $51 \cdot 3 \%$ (SD $\left.18.5 \%\right)$; three were current smokers and three ex-smokers of more than a year's duration. The sputum samples were ultracentrifuged at $50000 \mathrm{~g}\left(4^{\circ} \mathrm{C}\right)$ for 90 minutes and the supernatants assayed for TIMP and collagenase inhibitory capacity as described above. The coefficients of variation for TIMP and collagenase inhibition were calculated for each subject over the five days of study.

\section{EFFECT OF CORTICOSTEROIDS ON SPUTUM TIMP} AND COLLAGENASE INHIBITION

Nine subjects (six of them men) with chronic obstructive bronchitis were studied while in hospital for the assessment of a trial of corticosteroid treatment ( $40 \mathrm{mg}$ oral prednisone daily). All patients were studied at least four weeks after any infective episode. Their mean age was 53 (SD 7.8) years and the range 46-64. The mean $\mathrm{FEV}_{1} / \mathrm{FVC}$ was $42 \cdot 9 \%$ (SD $11 \cdot 7 \%$ ). All were current smokers. Sputum was collected during four hours early morning, as above for several days while the patients were having placebo treatment and then on each day of steroid treatment. Sputum from each patient collected on the last day of placebo treatment and the fifth day of corticosteroid treatment was assayed for TIMP concentration and collagenase inhibitory activity. Differences in TIMP and collagenase inhibitory activity were analysed with Student's $t$ test for paired data.

\section{BRONCHOALVEOLAR LAVAGE SAMPLES}

TIMP and collagenase inhibitory activity were measured (as above) in bronchoalveolar lavage samples obtained from six further subjects who were undergoing fibreoptic bronchoscopy in the investigation of suspected neoplasia. The radiographically normal lung was lavaged; premedication consisted of $600 \mu \mathrm{g}$ atropine sulphate intramuscularly and $5-10 \mathrm{mg}$ diazepam intravenously. Lignocaine was used for topical anaesthesia and the bronchoscope was wedged in the middle lobe or lingula. A total of $120 \mathrm{ml}$ of physiological saline was instilled in six aliquots, each aliquot being aspirated by gentle suction before introduction of the next one. Excess mucus was removed by filtering the lavage fluid through gauze and cells were removed by centrifugation at $400 \mathrm{~g}$. The lavage samples were concentrated fivefold by ultrafiltration and stored at $-70^{\circ} \mathrm{C}$ until they were analysed.

\section{GEL FRACTIONATION OF SPUTUM}

A pool of mucoid sputum $(10 \mathrm{ml})$ was applied to a 59 $\times 1.5 \mathrm{~cm}$ column packed with Sephacryl S300 (Phar- 
macia). Blue dextran and cytochrome $\mathrm{c}$ were added to the sputum as reference substances for column calibration. The column was eluted with $0.1 \mathrm{~mol} / 1$ Tris/ $\mathrm{HCl}$ buffer, $\mathrm{pH} 8.0$, containing $0.5 \mathrm{~mol} / 1 \mathrm{NaCl}$ at a rate of $36 \mathrm{ml} / \mathrm{h}$ and $6 \mathrm{ml}$ fractions were collected. Blue dextran and cytochrome concentrations in the fractions were determined by spectrophotometry at 615 and $413 \mathrm{~nm}$ respectively. TIMP concentrations in the fractions were measured as above, $\alpha_{1}$ antitrypsin and antileucoprotease by enzyme linked immunosorbent assay, ${ }^{16}$ and albumin by rocket immunoelectrophoresis.

The column elution curves were plotted for blue dextran and the above proteins. The curves were triangulated to give peak elution volume (Ve) and the column was calibrated on the basis of the known molecular weight of the reference proteins-namely, cytochrome c 11700; $\alpha_{1}$ antitrypsin 54000; albumin 64 500; antileucoprotease 10500 . The Ve blue dextran represented the void volume of the column. The molecular weight of TIMP in the fractionated sputum was calculated.

\section{Results}

DAILY VARIATION OF TIMP AND COLLAGENASE INHIBITORY ACTIVITY

TIMP and collagenase inhibitory activity were detected in all sputum samples collected from the six subjects over five consecutive days. The TIMP values ranged from 1.0 to $7.2 \mu \mathrm{g} / \mathrm{ml}$ (mean 3.76 , SD $1.5 \mu \mathrm{g} / \mathrm{ml}$ ). The average value for each day was relatively constant. The between subject coefficient of variation on each day ranged from $18.1 \%$ to $63 \%$ (mean $33.8 \%$ ). The within patient coefficient of variation over the five days ranged from $22.5 \%$ to $53.7 \%$ (mean $37.4 \%$ ).

The collagenase inhibitory activity in the sputum from the six subjects over the five days ranged from 0.9 to $12.4 \mathrm{U} / \mathrm{ml}$ (mean 2.70 (SD 2.1) $\mathrm{U} / \mathrm{ml}$ ). The between subject coefficient of variation on each day ranged from $24.9 \%$ to $105 \cdot 3 \%$ (mean $58.6 \%$ ). The within patient coefficient of variation over the five days for collagenase inhibitory activity ranged from $6.3 \%$ to $84.3 \%$ (mean $28 \cdot 4 \%$ ).

\section{TIMP}

\section{( $\mu \mathrm{g} / \mathrm{ml}$ )}

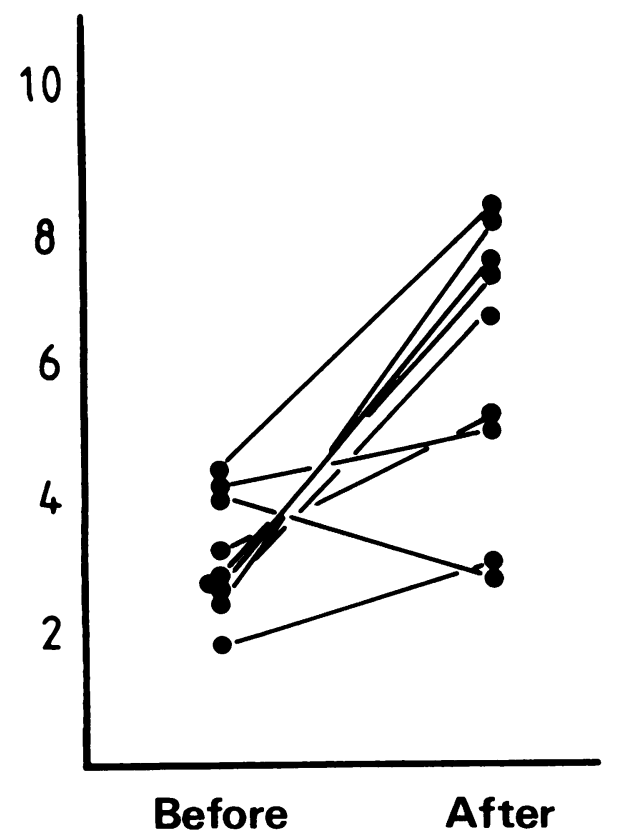

\section{CIA \\ (U/ml)}

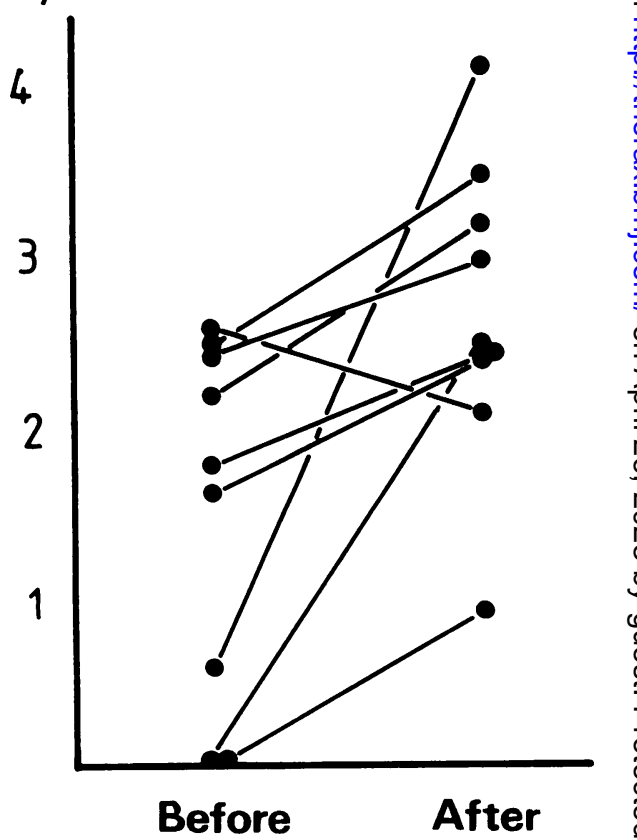

Fig 1 Individual values of tissue inhibitor of metalloproteinases (TIMP) and collagenase inhibitory activity (CIA) in sputum from nine patients with chronic bronchitis before and after treatment with oral prednisolone, $40 \mathrm{mg}$ daily. 


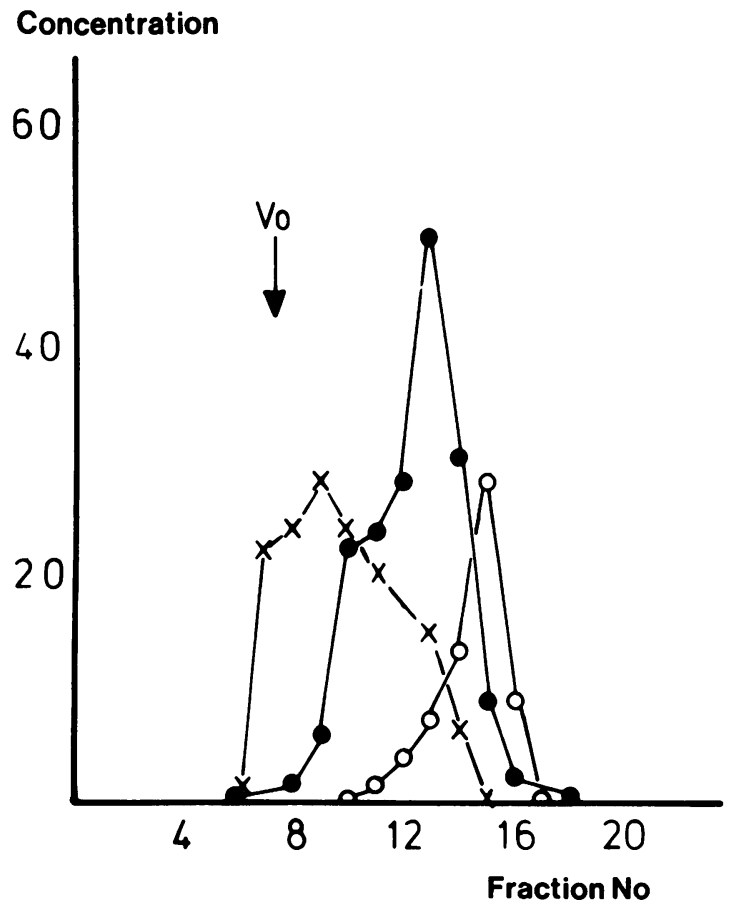

Fig 2 Elution profiles of albumin $(\times-\times)$, tissue inhibitor of metalloproteinases (TIMP) (○- ), and antileucoproteinase ( $\mathrm{O}-\mathrm{O}$ ) obtained after fractionation of sputum on Sephacryl S300. The void volume (Vo) of the column is shown. Concentrations shown are albumin $\mathrm{mg} / \mathrm{dl}$, antileucoproteinase $\mu \mathrm{g} / \mathrm{ml}$, and TIMP $\mu \mathrm{g} / 10 \mathrm{ml}$.

\section{EFFECT OF CORTICOSTEROIDS}

TIMP was present in the sputum from all nine patients with chronic bronchitis before and after corticosteroid treatment. The mean concentration before treatment was $3 \cdot 1$ (SD 0.87) $\mu \mathrm{g} / \mathrm{ml}$.

The sputum TIMP concentration increased in eight (fig 1) of the nine patients after five days' treatment (mean 5.8 (SD 1.9) $\mu \mathrm{g} / \mathrm{ml} ; 2 \mathrm{p}<0.005$ ). Collagenase inhibitory activity was observed in seven of the nine sputum samples before corticosteroid treatment (mean $1.53(1.1) \mathrm{U} / \mathrm{ml}$ ) and was present in all samples after five days' treatment (mean $2.69(0.92) \mathrm{U} / \mathrm{ml}$ ), having increased in eight of the nine patients (fig 1 ). Statistical analysis of the data for all nine subjects showed the results to be significant $(2 p<0.005)$.

\section{BRONCHOALVEOLAR LAVAGE SAMPLES}

TIMP was detected in all six bronchoalveolar lavage samples studied, the range of values being $0.45 \mathrm{ng} / \mathrm{ml}-2 \cdot 1 \mu \mathrm{g} / \mathrm{ml}$ (median $53 \mathrm{ng} / \mathrm{ml}$ ). Collagenase inhibitory activity was observed in only two of the six samples $(0.17$ and $0.75 \mathrm{U} / \mathrm{ml})$.
COMPARISON OF TIMP AND COLLAGENASE INHIBITORY ACTIVITY

In the assay system described here $4.2 \mathrm{U} / \mathrm{ml}$ of collagenase inhibitory activity represents the potential inhibitory activity of $1 \mathrm{mg} / \mathrm{ml}$ purified TIMP. The mean collagenase inhibitory activity of all the sputum samples collected $(n=48$ from variability and corticosteroid studies combined) when calculated from the TIMP concentrations is 16.9 (SD 7.5) $\mathrm{U} / \mathrm{ml}$; but the measured collagenase inhibitory activities in the samples were less than would be predicted from the TIMP concentrations, with a mean of $2.5(1.8) \mathrm{U} / \mathrm{ml}$. Similarly, the collagenase inhibitory activities of the bronchoalveolar lavage samples were lower than would be predicted from the amount of TIMP present and four of the lavage specimens showed no apparent inhibitory activity despite the presence of TIMP.

\section{MOLECULAR WEIGHT OF SPUTUM TIMP}

After the gel filtration of sputum on Sephacryl S300 TIMP was detected in fractions representing a single elution peak (fig 2). The calculated molecular weight of the sputum TIMP was 27500 .

\section{Discussion}

Human lung secretions have been reported to contain metalloproteinase activity. ${ }^{5-8}$ The role of these enzymes in contributing to connective tissue damage associated with chronic obstructive lung disease remains obscure; their action would depend on disturbance of the usual balance between the extracellular release of the enzymes and their inhibitors. The nature of metalloproteinase inhibitors in the lung secretions has not been investigated, although $\alpha_{2}$ macroglobulin, a potential inhibitor of these enzymes, ${ }^{17}$ is present in sputum ${ }^{18}$ and bronchoalveolar lavage samples. ${ }^{19}$ The $\alpha_{2}$ macroglobulin, in lung secretions, is, however, largely derived from the blood by transudation ${ }^{18}$ and, since it is a large protein, secretion concentrations are relatively low.

TIMP appears to be a major inhibitor of metalloproteinases in connective tissues ${ }^{10}$ and the present study shows that this protein is present in most sputum samples from patients with chronic obstructive bronchitis. Similarly, most of the samples showed the ability to inhibit metalloproteinase activity. The daily variation of sputum TIMP and collagenase inhibitory activity were similar to that described for other proteins. ${ }^{20}$

The theoretical capacity of the observed sputum TIMP to inhibit the collagenase activity in our assay system exceeded the actual inhibitory capacity of the samples as determined by comparison with the specific activity of the pure TIMP we used for standardisation. Sputum metalloproteinase inhibitors 
other than TIMP would be present; but even so the results suggest that the TIMP in the secretions was not fully active. This conclusion is supported by the absence of collagenase inhibitory capacity in some samples that were shown immunologically to contain TIMP. There are several possible explanations for this observation. Firstly, the specific activity of "lung" TIMP may differ from that of the purified protein. Secondly, since TIMP inhibits metalloproteinases by the formation of stable complexes, ${ }^{21}$ a proportion of the sputum TIMP may be in the form of inhibitor-enzyme complexes. The results from the gel filtration of sputum, however, suggested that the TIMP was largely in its native molecular form and not complexed. Thirdly, the sputum TIMP may be altered or inactivated by proteolytic cleavage in a manner perhaps similar to that described for $\alpha_{1}$ antitrypsin. ${ }^{12}$ Nothing is currently known about this potential mechanism with regard to TIMP but the calculated molecular weight of TIMP in sputum was 27500 , a value similar to that reported for the active purified protein (28000-28500). ${ }^{1214}$ The difference in molecular weight of only 500-1000 might represent limited proteolysis of sputum TIMP, but such a small difference could also be explained by the varying accuracy of the techniques for estimation of molecular weight. Other mechanisms for inactivation of TIMP may exist. For instance, the serine proteinase inhibitor $\alpha_{1}$ antitrypsin $\left(\alpha_{1}\right.$ proteinase inhibitor) is inactivated if a methionine residue at its active site is oxidised. ${ }^{22}$ The active site of TIMP, however, is not yet characterised and the effects of oxidants are unknown. Further studies on TIMP derived from the lung will be necessary to explain why it is less effective than expected at inhibiting metalloproteinases. Nevertheless, the results of the two assays moved in parallel and do indicate that the balance between metalloproteinases and their inhibitors in sputum from patients with chronic bronchitis usually favours the inhibitors.

The source of TIMP in lung secretions is likely to include fibroblasts, ${ }^{1011}$ epithelial cells, ${ }^{10}$ and macrophages. ${ }^{12}$ The relative contributions of these various cell types to the TIMP concentrations in lung secretions remain to be established.

Corticosteroid treatment is of potential benefit for correcting the balance between proteinases and their inhibitors in the lung. It has been shown that corticosteroid treatment is accompanied by an increase in the inhibitory capacity of $\alpha_{1}$ antitrypsin in the sputum of patients with chronic bronchitis, ${ }^{23}$ as well as a reduction in the transudation of plasma proteins from the blood to the secretions. ${ }^{24}$ Since $\alpha_{1}$ antitrypsin in lung secretions is derived from the blood, ${ }^{25}$ its increased inhibitory capacity was thought to represent reduced serine proteinase activity rather than a direct increase in $\alpha_{1}$ antitrypsin concentration in $\underset{\vec{\rho}}{\overrightarrow{\vec{S}}}$ secretions. ${ }^{23}$ The present study has shown that corti- $\bar{C}$ costeroids increase the capacity of sputum to inhibit collagenase. In parallel, TIMP concentrations in spu- $\frac{\bar{T}}{\vec{D}}$ tum were increased. Thus, although corticosteroids $\underset{\square}{\mathbb{Q}}$ may have resulted in reduced extracellular release of metalloproteinases, the increased collagenase $\vec{\theta}$ inhibition does appear to reflect an increased concen- $?$ tration of TIMP in the secretions. The reasons for the $\overrightarrow{\vec{\omega}}$ increased TIMP concentration and collagenase $\stackrel{\mathscr{\sigma}}{\circ}$ inhibitory activity in the sputum of patients receiving $\overrightarrow{\vec{x}}$ corticosteroids are not clear. Possibly corticosteroids $\stackrel{\leftrightarrow}{\rightarrow}$ reduced the volume or degree of hydration of the lung secretions. Alternatively, the steroid treatment may have directly stimulated TIMP synthesis by lung tis- $\vec{f}$ sues. This hypothesis is supported by the observation 0 that corticosteroids can increase the production of TIMP as well as reducing collagenase secretion by $\vec{O}$ connective tissues in vitro. ${ }^{13}$ Further studies will be $\frac{9}{\circ}$ required, but these results suggest a beneficial effect of $\frac{0}{8}$ corticosteroids in increasing the concentration of metalloproteinase inhibitor in lung secretions.

Studies of sputum do not fully clarify the role of $\stackrel{\infty}{\infty}$ TIMP at the bronchoalveolar level, where the release of metalloproteinase could have a role in the development of emphysema. We therefore performed a preliminary study of the TIMP concentration and collagenase inhibitory activity in bronchoalveolar $\stackrel{\mathbb{D}}{\stackrel{2}{2}}$ lavage samples from six patients undergoing diagnos- $\underset{\vec{F}}{\vec{F}}$ tic bronchoscopy for carcinoma of the bronchus. 의 TIMP was detected in all but collagenase inhibitory activity was observed in only two of the six lavage samples. These results indicate that bronchoalveolar lavage fluid also contains inactive TIMP, and further studies of the balance between metalloproteinases $\underset{\otimes}{\stackrel{Q}{\otimes}}$ and their inhibitors in the lower respiratory tract are $\bar{\sigma}$ clearly indicated. It would also be fruitful to investigate the major source or sources of TIMP and $\delta$ collagenase in the lung by their immunolocalisation in pulmonary tissue.

\section{References}

1 Stockley RA. Proteolytic enzymes, their inhibitors and lung disease. Clin Sci 1983;64:119-26.

2 Janoff A. Elastases and emphysema. Current assessment $\mathrm{\omega}$ of the protease-antiprotease hypothesis. Am Revo Respir Dis 1985;132:417-33.

3 Senior RM, Tegner H, Kuhn C, Ohlsson K, Starcher BC, Pierce JA. The induction of pulmonary emphysema with leukocyte elastase. Am Rev Respir? Dis 1977;116:469-75.

4 Eriksson S. Studies in $\alpha_{1}$-antitrypsin deficiency. Acta $\underset{\overparen{D}}{\stackrel{O}{(19}}$ Med Scand 1965;177:1-85.

5 Niederman MS, Fritts LL, Merrill WW, et al. Demonstration of free elastolytic metalloenzyme in humano lung lavage fluid and its relationship to alpha $1^{-}$ 
antiprotease. Am Rev Respir Dis 1984;129:943-7.

6 Tournier J-M, Jacquot J, Puchelle E, Bieth JG. Evidence that Pseudomonas aeruginosa elastase does not inactivate the bronchial inhibitor in the presence of leukocyte elastase. Am Rev Respir Dis 1985;132:524-8.

7 Gadek JE, Kelman JA, Fells G, et al. Collagenase in the lower respiratory tract of patients with idiopathic pulmonary fibrosis. $N$ Engl J Med 1979;301:737-42.

8 Johnson AR, Ashton J, Schultz WW, Erdos EG. Neutral metalloendopeptidase in human lung tissue and cultured cells. Am Rev Respir Dis 1985;132:564-8.

9 Gadek JE, Fells GA, Zimmerman RL, Crystal RG. The normal human lower respiratory tract is relatively deficient in anticollagenase activity. Am Rev Respir Dis 1981;123:224.

10 Hembry RH, Murphy G, Reynolds JJ. Immunolocalisation of tissue inhibitor of metalloproteinases (TIMP) in human cells. Characterization and use of a specific antiserum. J Cell Sci 1985;73:105-19.

11 Stricklin GP, Welgus HG. Human skin fibroblast collagenase inhibitor: purification and biochemical characterization. J Biol Chem 1983;258:12252-8.

12 Welgus HG, Campbell EJ, Bar-Shavit Z, Senior RM, Teitelbaum SL. Human alveolar macrophages produce a fibroblast-like collagenase and collagenase inhibitor. J Clin Invest 1985;76:219-24.

13 McGuire MKB, Meats JE, Ebsworth NH, Murphy G, Reynolds JJ, Russell RGG. Messenger function of prostaglandins in cell to cell interactions and control of proteinase activity in the rheumatoid joint. Int $J$ Immunopharmacol 1982;4:91-102.

14 Murphy G, Cawston TE, Reynolds JJ. An inhibitor of collagenase from human amniotic fluid. Biochem $J$ 1981;195:167-70.

15 Medical Research Council Committee on the Aetiology of Chronic Bronchitis. Definition and classification of chronic bronchitis for clinical and epidemiological purposes. Lancet 1965;i:775-9.
16 Kramps JA, Franken C, Dijkman JH. ELISA for quantitative measurement of low-molecular-weight bronchial protease inhibitor in human sputum. Am Rev Respir Dis 1984;129:959-63.

17 Werb Z, Burleigh MC, Barrett AJ, Starkey PM. The interaction of $\alpha_{2}$-macroglobulin with proteinases. Binding and inhibition of mammalian collagenases and other metal proteinases. Biochem $J$ 1974;139: $359-68$.

18 Burnett D, Stockley RA. Serum and sputum $\alpha_{2}$-macroglobulin in patients with chronic obstructive airways disease. Thorax 1981;36:512-6.

19 Gadek JE, Fells GA, Zimmerman RL, Rennard SI, Crystal RG. Antielastases of the human alveolar structures. Implications for the protease-antiprotease theory of emphysema. J Clin Invest 1981;68:889-98.

20 Wiggins J, Stockley RA. Variability in sputum sol-phase proteins in chronic obstructive bronchitis. Am Rev Respir Dis 1983;128:60-4.

21 Cawston TE, Murphy G, Mercer E, Galloway WA, Hazleman BL, Reynolds JJ. The interaction of purified rabbit bone collagenase with purified rabbit bone metalloproteinase inhibitor. Biochem $J$ 1983; 211:313-8.

22 Johnson D, Travis $J$. The oxidative inactivation of human $\alpha_{1}$-proteinase inhibitor. $J$ Biol Chem 1979; 254:4022-6.

23 Morrison HM, Afford SC, Stockley RA. Inhibitory capacity of alpha ${ }_{1}$-antitrypsin in lung secretions: variability and the effect of drugs. Thorax 1984;39:510-6.

24 Wiggins J, Elliot JA, Stevenson RD, Stockley RA. Effect of corticosteroids on sputum sol-phase protease inhibitors in chronic obstructive pulmonary disease. Thorax 1982;37:652-6.

25 Stockley RA, Burnett D. Alpha ${ }_{1}$-antitrypsin and leukocyte elastase in infected and non-infected sputum. $\mathrm{Am}$ Rev Respir Dis 1979;120:1081--6. 